\title{
WEAR AND HEAT CHARACTERIZATION OF BOTH THE AS-CAST AND HEAT EXPOSED SPECIMENS FOR AL/SIC PARTICULATE COMPOSITES
}

\author{
M. M. Dewidar ${ }^{1} \quad, \quad$ Khalil.A. Khalil ${ }^{1,2}$, and Sug-Won Kim ${ }^{2}$ \\ ${ }^{1}$ Department of Mechanical Design and Materials, High Institute of \\ Energy, South Valley University, Aswan, Egypt \\ ${ }^{2}$ Division of Advanced Materials Engineering, RIAMD, Chonbuk National \\ University, Jeonju 561-756, South Korea
}

(Received June 15, 2006 Accepted August 30, 2006)

\begin{abstract}
This Study is to investigate on the wear characterization and heat resistance of aluminum/silicon carbide $(\mathrm{Al} / \mathrm{SiC})$ with different particles (3, 5, and $10 \mu \mathrm{m})$ composites manufactured by duplex process, which consists of squeeze-infiltration and squeeze casting. Also, this study is to investigate the effect of alloying element $(\mathrm{Ni})$ on the microstructure, wear behavior and heat resistance of $\mathrm{Al} / \mathrm{SiC}$ composite. Owing to the increase in interfacial area between SiC particles and matrix in both the as-cast and heat exposed specimens (at $250{ }^{\circ} \mathrm{C}$ and $350{ }^{\circ} \mathrm{C}$ for $5 \mathrm{hr}$ ), the decrease in nano-SiC particles size resulted in the increase in the hardness of composites. And in case of $3 \mu \mathrm{m}$ SiC reinforced Al composites as compared with other composites, the highest density of dislocation was generated during manufacture. Composite with $3 \mu \mathrm{m}$ SiC has the lowest wear amount among composites reinforced with 5 and $10 \mu \mathrm{m} \mathrm{SiC}$. Heat resistant property was improved with increasing Ni addition content (wt.) in $\mathrm{Al} / \mathrm{SiC}$ composites. The wear resistance at $200{ }^{\circ} \mathrm{C}$ in argon gas on composite was greater than those at $200{ }^{\circ} \mathrm{C}$ and room temperature in the as-composites.
\end{abstract}

\section{INTRODUCTION}

Metal matrix composite materials are advanced materials, which combine tough metallic matrix with a hard ceramic or soft reinforcement to produce composite materials [1]. These materials have superior properties compared to the monolithic materials and can be tailarable to a specific applications [2]. In recent years the aerospace, military and automotive industries have been promoting the technological development of composite materials to achieve good mechanical strength/density and stiffness/density ratios. Nano-ceramic particle reinforced composites have the good characteristics that are good formability, lower fabrication cost, good heat and wear resistance due to unique particle's properties and dispersion compared with the fiber reinforced composites. $\mathrm{Al}-\mathrm{SiC}$ composites offer isotropic improvements in structural properties over their corresponding base alloys at a reasonable cost, particularly as they can often be produced and formed via conventional metallurgical routes [3]. In addition to their increased specific stiffness and strength over monolithic alloys, $\mathrm{Al}-\mathrm{SiC}$ composites have been selected for specific engineering applications for their improved smooth specimen fatigue resistance over unreinforced alloys [4-8]. It is now well understood that the reinforcement content and nature of its distribution in the matrix of the composite have profound influence on the performance of composites [9-11]. However, it is difficult to make the homogeneous distribution of particles in the Al-matrix in case of subseive size (below $10 \mu \mathrm{m}$ ) particle. Therefore, a new duplex 
process has been developed to produce $\mathrm{Al}$ matrix composite with homogeneous distribution of subseive size particles. In present study, the characteristics of the heat resistance and alloying element effects in $\mathrm{SiC}$ reinforced $\mathrm{Al}$ matrix composites manufactured by duplex process were investigated by using Optical Microscope (OM), X-Ray Diffractometer (XRD), Differntial Scanning Clorimetry DSC and Scanning Electronic Microscope (SEM). Also, wear characteristics at ambient, elevated temperature $\left(200{ }^{\circ} \mathrm{C}\right)$ and $200{ }^{\circ} \mathrm{C}$-Ar were investigated.

\section{EXPERIMENTAL PROCEDURES}

In the first stage for preparing the precomposite, starting material ( Pure Al ) was melted in electric furnace with other alloys of $\mathrm{Al}-25 \% \mathrm{Si}, \mathrm{Al}-50 \% \mathrm{Cu}$ under argon atmosphere at $740^{\circ} \mathrm{C}$. The chemical composition of the initial matrix alloy is given in Table 1. Ni element was added to examine effects of alloying element on hardness and wear resistance. In squeeze infiltrating die, $(3,5$, and $10 \mu \mathrm{m}) \mathrm{SiC}$ bed was preheated up to $600{ }^{\circ} \mathrm{C}$ and then the melt was poured into the die at $700{ }^{\circ} \mathrm{C}$. To infiltrate by squeeze at $680{ }^{\circ} \mathrm{C}$, the hydraulic ram was used to apply a pressure of $50 \mathrm{MPa}$ to the molten metal until completion of eutectic reaction. In the second stage, the matrix alloy was melted in electric furnace with pre-composite for designed $10 \mathrm{wt} \% \mathrm{SiC}$ reinforced Al matrix alloy at $720^{\circ} \mathrm{C}$, mechanically agitated at $600 \mathrm{rpm}$ and then solidified under pressure of $75 \mathrm{MPa}$ until $500{ }^{\circ} \mathrm{C}$. SEM and OM were used to investigate the distribution of $\mathrm{SiC}$ particles. Hardness was measured on the B scale with steel ball indenter and a $100 \mathrm{~kg}$ major load in Rockwell hardness tester. All specimens were tested to investigate the wear characteristics such as wear loss amount and the morphology of worn surface by using a TE88P wear tester of the pin on disc type under the conditions (final load: $100 \mathrm{~N}$, sliding distance: $4000 \mathrm{~m}$, sliding speed: $0.64 \mathrm{~m} / \mathrm{s}$, room temperature (RT) and elevated temp.: $200{ }^{\circ} \mathrm{C}$ with and without Argon gas).

Table 1. The chemical composition of the initial matrix alloy.

\begin{tabular}{|r|c|c|c|c|c|}
\hline Element & $\mathrm{Si}$ & $\mathrm{Cu}$ & $\mathrm{Fe}$ & $\mathrm{Mg}$ & $\mathrm{Al}$ \\
\hline Wt.\% & 7.77 & 2.72 & 0.55 & 0.28 & Bal. \\
\hline
\end{tabular}

\section{RESULTS AND DISCUSSION}

\subsection{Microstructures And Sic Particles Distribution}

In general, when adding into the melt, the subsieve size $\mathrm{SiC}$ floats onto the surface of the melt, because of large specific surface. Therefore, it is difficult to make the composite reinforced homogeneously subsieve size particle of under $10 \mu \mathrm{m}$. But the wettability of particle of 3,5 and $10 \mu \mathrm{m}$, used in this study was improved due to formation of activated surface on $\mathrm{SiC}$ surface through squeeze infiltrating process for making the pre-composite. So, in order to make subseive size (under $10 \mu \mathrm{m}$ ) $\mathrm{SiC}$ distribution homogeneously, duplex process which consists of squeeze infiltration process (1st step) and squeeze casting was used for making specimens used in this study.

The optical micrographes of $\mathrm{Al} / 10 \mathrm{wt} . \% \mathrm{SiC}$ composites fabricated by duplex processing were shown in Figure 1. The $\mathrm{SiC}$ particles was generally distributed homogeneously due to the formation of active surface on $\mathrm{SiC}$ of the precomposite fabricated by squeeze infiltrating process and the microstructures became finer due to an increase in the cooling rate by applying pressure of a squeeze casting. However, compare with other specimens reinforced with particle of $5,10 \mu \mathrm{m} \mathrm{SiC}$, a dispersion uniformity of $3 \mu \mathrm{m} \mathrm{SiC}$ reinforced composite appeared low because of the pushing effect in growing dendrite arm and great coalescencing force between particles with great specific surface. 
Figure 2 shows optical micrographs of Ni added composites. The distribution of $\mathrm{SiC}$ particles became homogeneous by the addition of $\mathrm{Ni}$ in composite. This is because $\mathrm{Ni}$ addition makes the increase in eutectic temperature, as a result mushy zone is shortened.

By the addition of finer $\mathrm{SiC}$ particle in aluminum matrix, the distribution of $\mathrm{SiC}$ particle became inhomogeneous. But the distribution of $\mathrm{SiC}$ particle became homogeneous with not only an addition of $\mathrm{Ni}$ but also with an increase of $\mathrm{Ni}$ content.

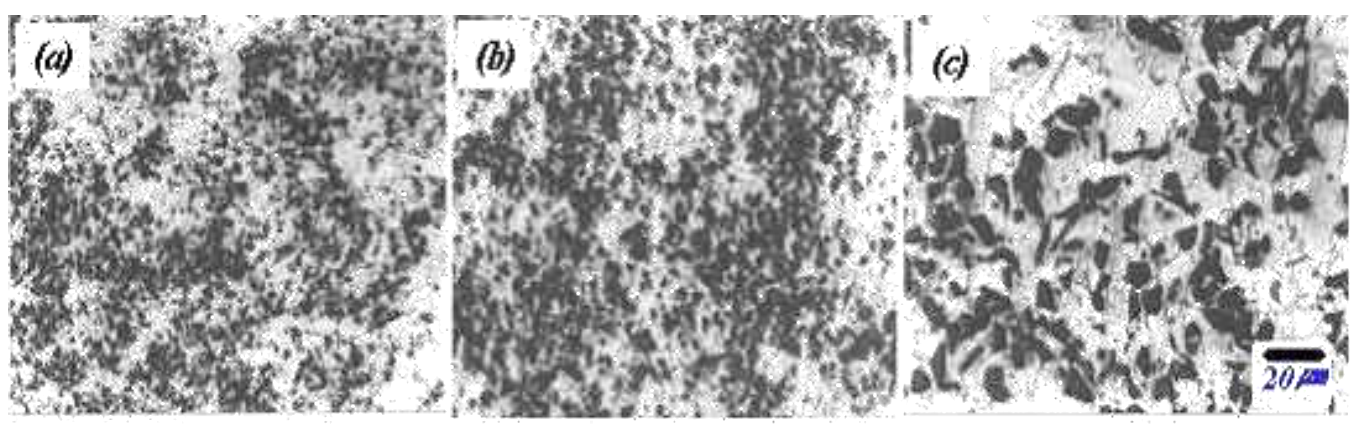

Figure 1. Optical microstructures of final composites with various $\mathrm{SiC}$, $\begin{array}{llll}\text { size (a) } 3 \mu \mathrm{m} & \text { (b) } 5 \mu \mathrm{m} & \text { (c) } 10 \mu \mathrm{m} \text {. }\end{array}$

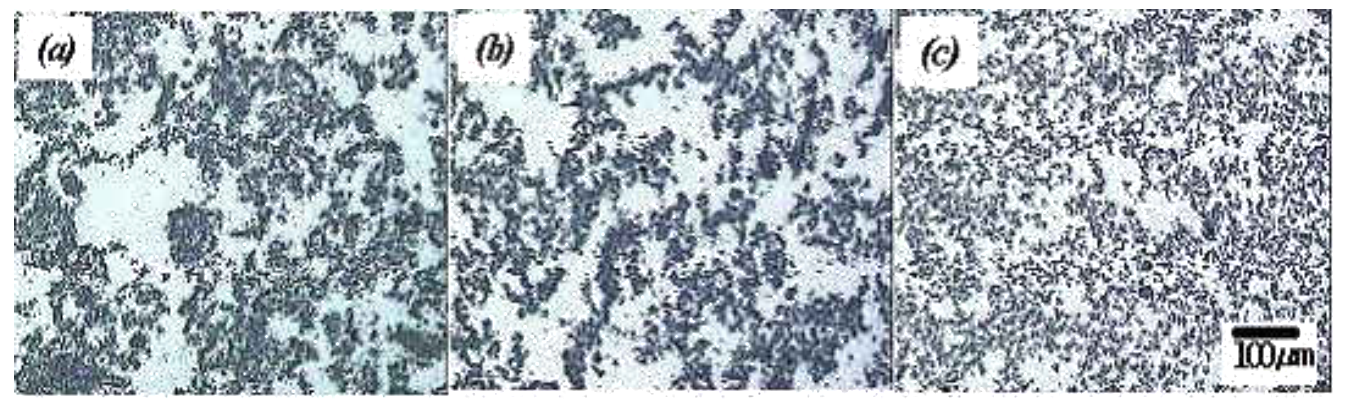

Figure 2. Variation of microstructures with $\mathrm{Ni}$ addition in $5 \mathrm{um} \mathrm{SiC}$ reinforced composite (a) $5 \mu \mathrm{m}$ (b) $5 \mu \mathrm{m}-1 \% \mathrm{Ni}$ (c) $5 \mu \mathrm{m}-3 \% \mathrm{Ni}$.

\subsection{Hardness}

The changes of hardness in $\mathrm{Al} / \mathrm{SiC}$ composite with the various particle sizes and addition of Ni before and after heat exposure were shown in Figure 3. In Figure 3(a), a composite reinforced by $\mathrm{SiC}$ has higher hardness compare to a cast non-reinforced. It is caused by a particle dispersion reinforcement by SiC. A hardness increases with the size of SiC become more finer. This is because the formation of dislocation by the difference of heat expansion coefficient between $\mathrm{SiC}$ and $\mathrm{Al}$ matrix [12]. A hardness of heat exposured specimens at $250^{\circ} \mathrm{C}$ for $5 \mathrm{hr}$ is higher than as-cast specimens. This is because a formation of aging precipitation by heat exposure. It is thought that hardness is increased by the formation of $\theta^{\prime}$ phase and $\lambda\left(\mathrm{Al}_{5} \mathrm{Cu}_{2} \mathrm{Mg}_{8} \mathrm{Si}_{5}\right)$ [12]. The reason of increasing the hardness at $3 \mu \mathrm{m}$ is because the formation of precipitations is formed more rapidly by high dislocation density.

Also at Figure 3(b), hardness value was increased continuously with addition of Ni. Because of eutectic temperature was increased by addition of $\mathrm{Ni}, \alpha-\mathrm{Al}$ become more 
finer. Also the reason of increasing the hardness is because the intermetallic compound of $\mathrm{NiAl}_{3}$, and $\mathrm{NiAl}_{2}$ [13] which is more securer and harder at the high temperature was formed.

\subsection{XRD}

Intermetallic compound was identified by XRD in order to observe the compound behavior during heat exposure and the results were shown in Figure 4. Only aging precipitation of $\mathrm{Al}_{2} \mathrm{Cu}$ appeared at $\mathrm{Ni}$ non-addition composite. But $3 \% \mathrm{Ni}$ added $\mathrm{Al} / \mathrm{SiC}$ composite formed intermetallic compound of $\mathrm{NiAl}_{3}$ which is stable at high temperature as well as $\mathrm{Al}_{2} \mathrm{Cu}$.
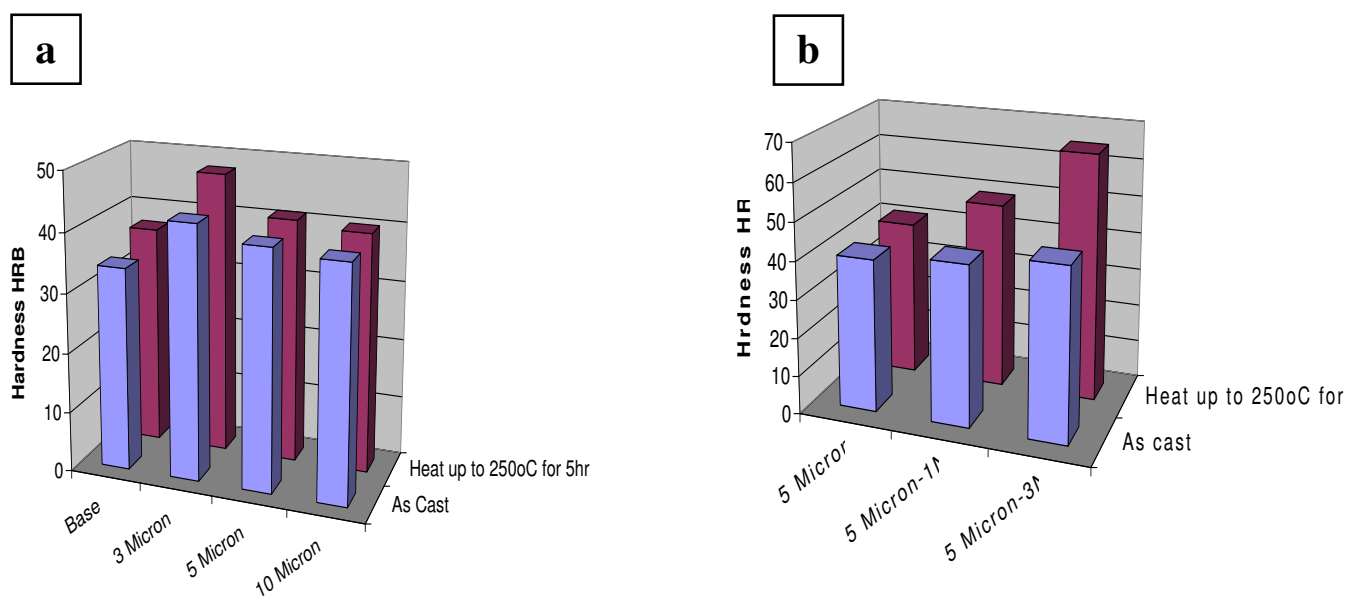

Figure 3. Hardness of as-cast and heat-exposed specimens at $250 \mathrm{oC}$ for $5 \mathrm{hrs}$ a) without $\mathrm{Ni}$ addition, and b) with $\mathrm{Ni}$ addition
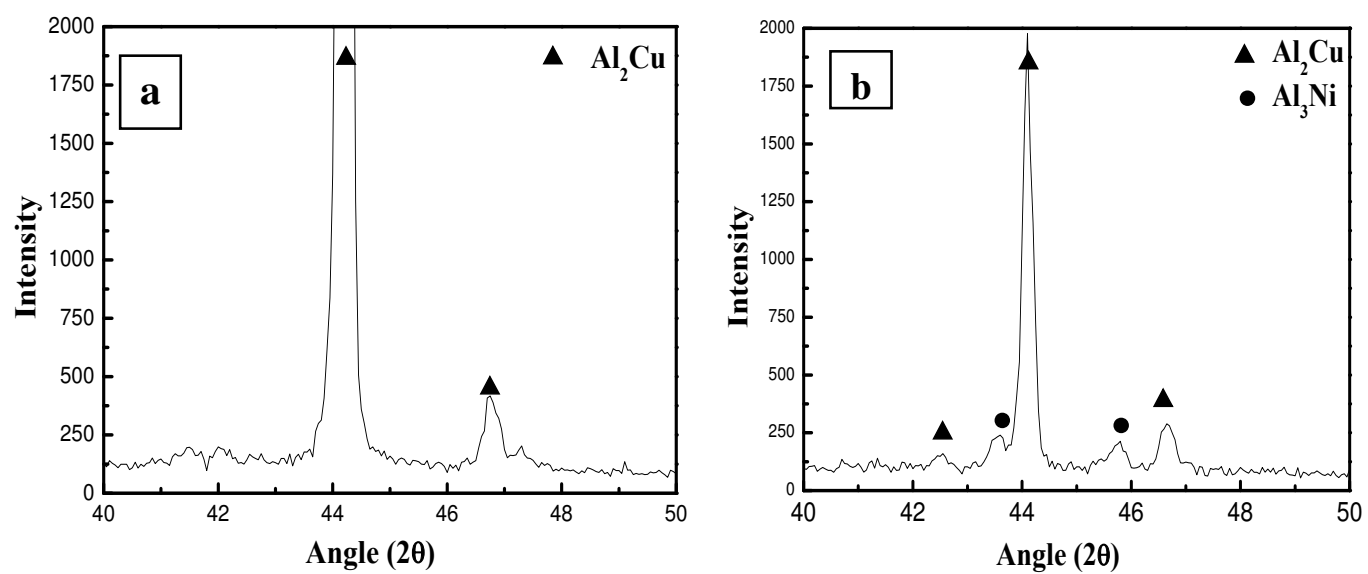

Figure 4. X-ray diffraction analysis of heat exposed specimens at $250^{\circ} \mathrm{C}$ for $5 \mathrm{hr}$,

(a) Al-7.76Si-2.75Cu-0.28Mg/10wt.\%SiCp, and

(b) Al-7.76Si-2.75Cu-0.28Mg-3Ni/10wt.\%SiCp. 
Figure 5 shows the elemental dot mapping results of the specimen using SEM. Figure 5(a) shows the morphology of $3 \%$ Ni added composite, (b) of $\mathrm{Al}$ dot mapping, (c) of $\mathrm{Ni}$ dot mapping and (d) of $\mathrm{Cu}$ dot mapping. As a result of the elemental dot mapping, it could be confirmed that the formation of intermetallic compounds consisted of $\mathrm{Al}, \mathrm{Ni}$ and $\mathrm{Cu}$ elements.

(a)

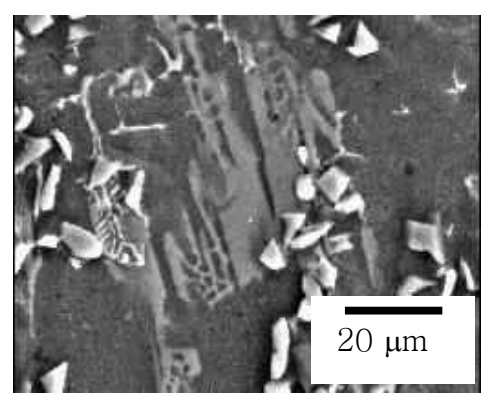

(c)

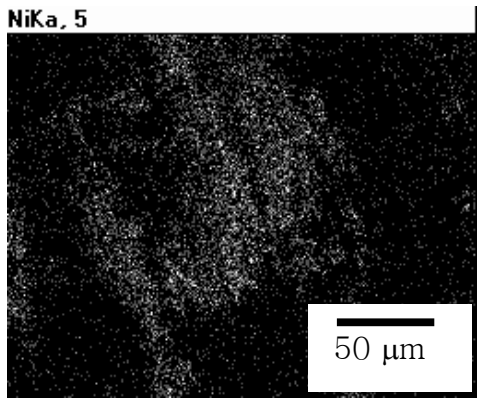

(b)

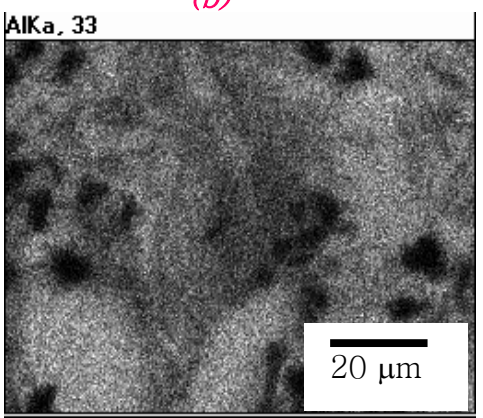

(d)

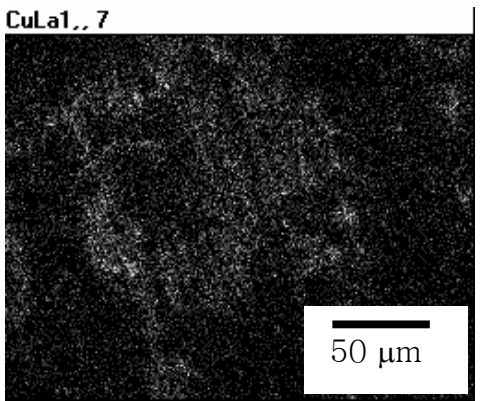

Figure 5. Dot mapping of intermetallic compounds (a) SEM (3\%Ni) (b) Al dot mapping (c) Ni dot mapping, and (d) Cu dot mapping.

\subsection{Wear Behavior of As-Cast and Heat Exposed Specimens at room temperature}

Figure 6(a) shows the wear amount of heat exposed composite and as-composite. Wear amount of composite $(3 \mu \mathrm{m})$ has less than that of composite $(5 \mu \mathrm{m})$, because SiC $(3 \mu \mathrm{m})$ was acted as lubricant agent during abrasive wear. Also, wear resistance of heat exposed specimen for $5 \mathrm{hr}$ at $250^{\circ} \mathrm{C}$ was improved more than as-composite. This is because the hardness was increased by aging effect caused by heat exposure for $5 \mathrm{hr}$ at $250^{\circ} \mathrm{C}$. The composite exposed at $350^{\circ} \mathrm{C}$ for $5 \mathrm{hr}$ appeared large wear amount more than that of non-heat exposed specimen. It is considered because $\mathrm{Si}$ of $\alpha$-Al was diffused into a near eutectic region, so its hardness was decreased. Figure 6(b) showed the changes of wear amount according to heat exposure temperatures $\left(250^{\circ} \mathrm{C}, 350^{\circ} \mathrm{C}\right)$ and $\mathrm{Ni}$ addition. Wear amount of composite $(5 \mu \mathrm{m})$ added $3 \mathrm{wt} \% \mathrm{Ni}$ has less than that of composite $(5 \mu \mathrm{m})$. The wear amount of heat exposed specimen for $5 \mathrm{hr}$ at $250^{\circ} \mathrm{C}$ decreased than that of R.T and $350^{\circ} \mathrm{C}$. This is because hardness is increased by the formation of $\theta^{\prime}$ phase and $\lambda\left(\mathrm{Al}_{5} \mathrm{Cu}_{2} \mathrm{Mg}_{8} \mathrm{Si}_{5}\right)$ [12] during heat exposure at $250^{\circ} \mathrm{C}$. It is confirmed through worn surface and debris as shown in Figure 8. Worn surface of 5 micron heat-exposed at $350^{\circ} \mathrm{C}$ appeared adhesive wear and worn debris became coalesenceing (Figure 8). Figure 7 shows the variation of worn surface and debris 
according to particle sizes in composites reinforced various particles. The worn surface of base alloy appeared the abrasive and fusion wear phenomenon. The worn surface of $3 \mathrm{M}$ has abrasive morphology of very smooth type. Abrasive wear mechanism appears because of the seperated SiC acted as a lubricant on worn surface while wear is processing. Also debris of 10 micron was formed as bloky type broke out worn surface which caused by the adhesive and friction wear mechanism.
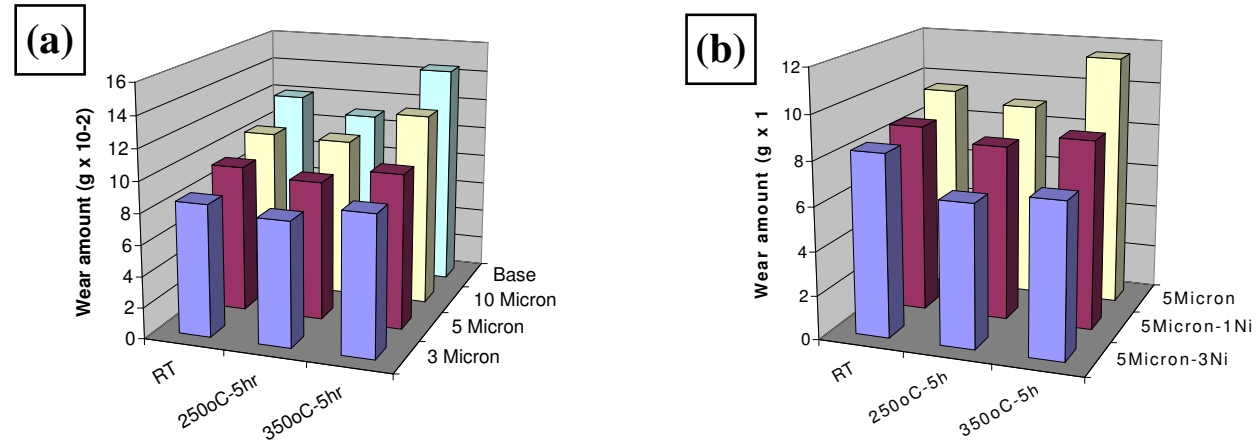

Figure 6. Wear amount after heat exposure at $250^{\circ} \mathrm{C}$ and $350^{\circ} \mathrm{C}$ for $5 \mathrm{hrs} \mathrm{a)}$ $\mathrm{Al} / \mathrm{SiC}$ composites, and b) composite with $\mathrm{Ni}$ addition.
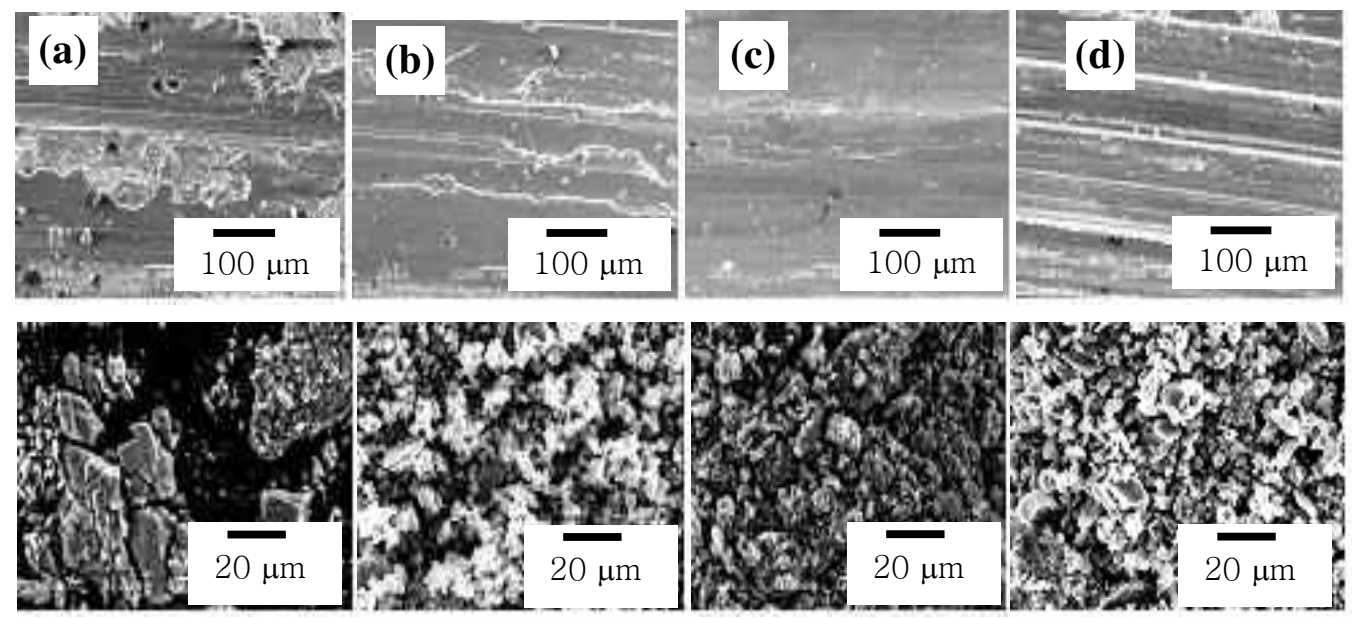

Figure 7. SEM of worn surface and debris in alloy composites with different SiC particle size in matrix alloy (a) base alloy (b) $3 \mathrm{M}$ (c) $5 \mathrm{M}$ and (d) $10 \mathrm{M}$.

\subsection{Wear Behavior of As-Cast and Heat Exposed Specimens at Elevated Temperature}

Figure 9 (I) shows the results of wear test of $3 \mu \mathrm{m}$ composite under the various conditions. As shown in this figure, the wear amount in specimen increased drastically at elevated temperature, compared with room temperature. The worn surface morphology of $200^{\circ} \mathrm{C}$-Ar wear specimen shows adhesive and abrasive wear phenomena, otherwhile adhesive and fusion morphologies were appeared that the debris was formed coarsely in case of $200^{\circ} \mathrm{C}$ wearing specimen. Using SEM and OM, the reason of significant decrease in wearing amount when purging argon gas was 
clarified by Figure 9 (II). As shown in Figure 10(II), the tribological layer (30-60 $\mu \mathrm{m}$ thickness) with agglomerate of $\mathrm{SiC}$ reinforcement was form in worn surface and 3-4 $\mu \mathrm{m} \mathrm{Al}_{2} \mathrm{O}_{3}$ layer in the edge of its layer was form. The hardness of tribological layer is two times higher than that of the as-cast and higher hardened layer prevents worn surface from wearing. As a result, wear amount of $200^{\circ} \mathrm{C}-\mathrm{Ar}$ composites decreased than that of 200-composites. Without Ar gas purging during wear test at $200^{\circ} \mathrm{C}$, the tribological layer was not formed, instead ferro-oxide layer $\left(\mathrm{Fe}_{2} \mathrm{O}_{3}: 7-8 \mu\right.$ m thickness ) was formed. This is because that the matrix temperature of composite during wear test without Ar gas became higher than that of composite with Ar gas purging, and the matrix became softer.

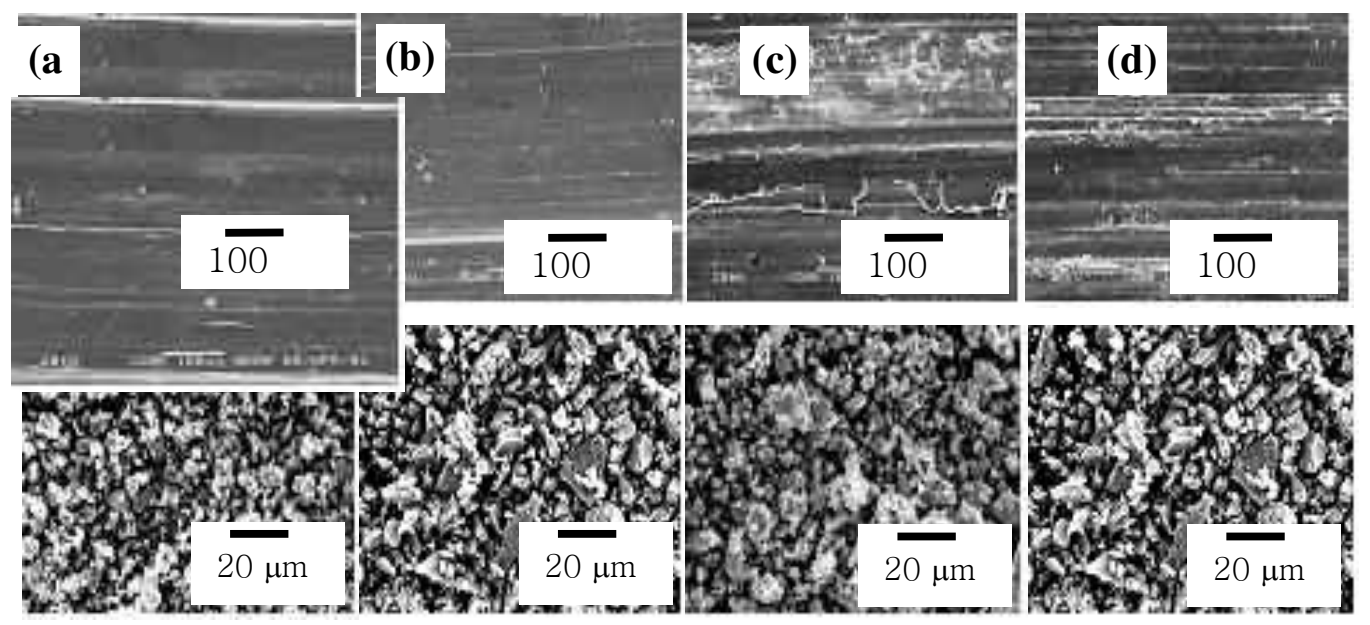

Figure 8. SEM of worn surface and debris according to different exposure temperatures for $5 \mathrm{hr}$ (a) $5 \mathrm{M}-250^{\circ} \mathrm{C}$ (b) $5 \mathrm{M}-3 \mathrm{Ni}-250^{\circ} \mathrm{C}$ (c) $5 \mathrm{M}-350^{\circ} \mathrm{C}$ and (d) $5 \mathrm{M}-3 \mathrm{Ni}-350^{\circ} \mathrm{C}$.

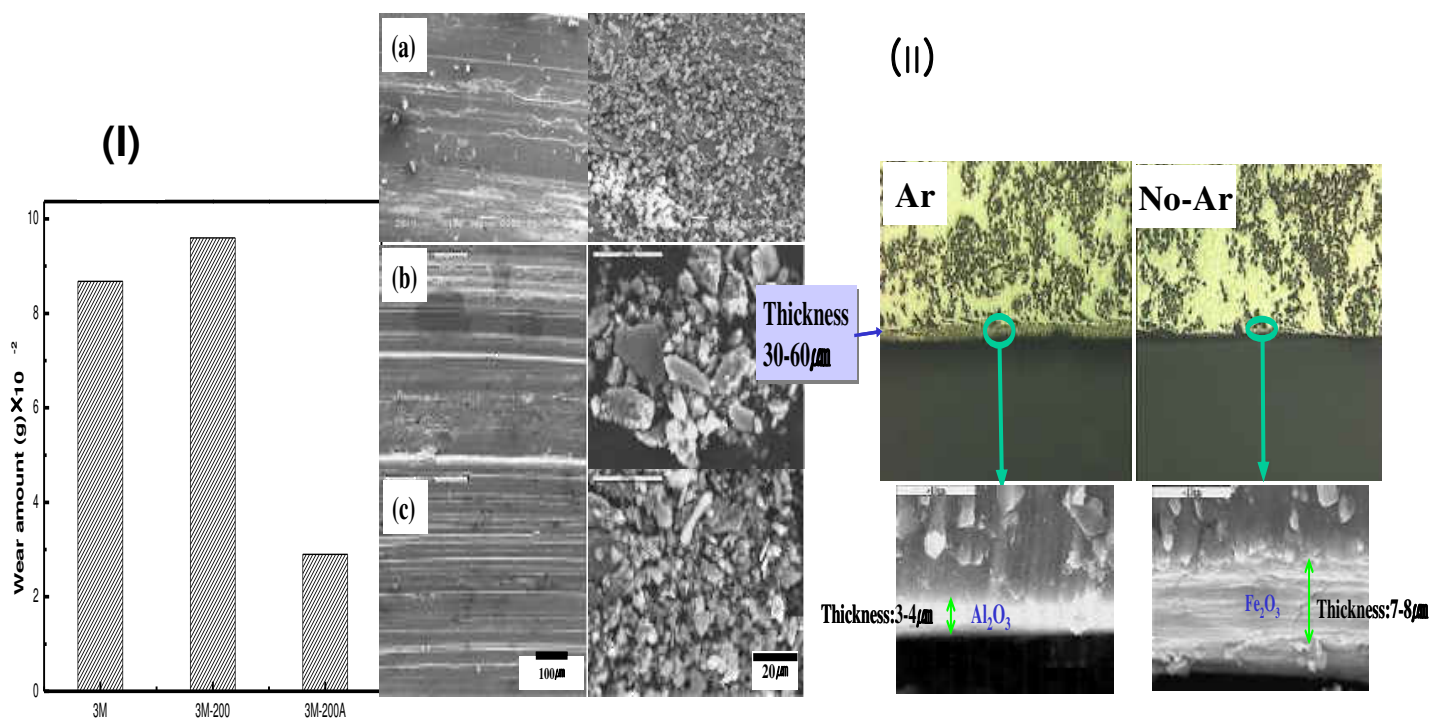

Figure 9. Wear amount and OM, SEM of worn surface and debris according to the wear conditions in $3 \mu \mathrm{m}$ composite (a) R.T (b) $200^{\circ} \mathrm{C}$, and (c) $200^{\circ} \mathrm{C}-\mathrm{Ar}$. 
Figure 10 shows the relationship between wear amount, SEM of worn surface, and debris of composites according to wear conditions. In this figure, (a) is under the atmosphere of room temperature, (b) $200^{\circ} \mathrm{C}$ (c) $200^{\circ} \mathrm{C}$-Ar gas. The $3 \mu \mathrm{m} \mathrm{SiC} \mathrm{composite}$ experienced with exposure of $250^{\circ} \mathrm{C}$ before wear test was used in wear test as shown in Figure 10. Also the wear amount of $200^{\circ} \mathrm{C}$ composite was greater those of ascomposite and $200^{\circ} \mathrm{C}$-Ar composite. The wear behavior of $200^{\circ} \mathrm{C}$-Ar composite was dominated by the mixture of adhesive and abrasive wear mechanism, otherwhile that of $200^{\circ} \mathrm{C}$ composite was dominated by fusion wear mechanism. The debris of $200^{\circ} \mathrm{C}$ composite was larger than those of both as-composite and $200^{\circ} \mathrm{C}$-Ar composite. As shown in the photos, tribo-layer consisted of mixture of $\mathrm{SiC}$ agglomerate was formed on the surface of composite when purging with Ar gas. Without Ar gas, tribo-layer as mentioned above was not formed, instead $\mathrm{Al}$ and $\mathrm{Fe}$ oxides layer was found.

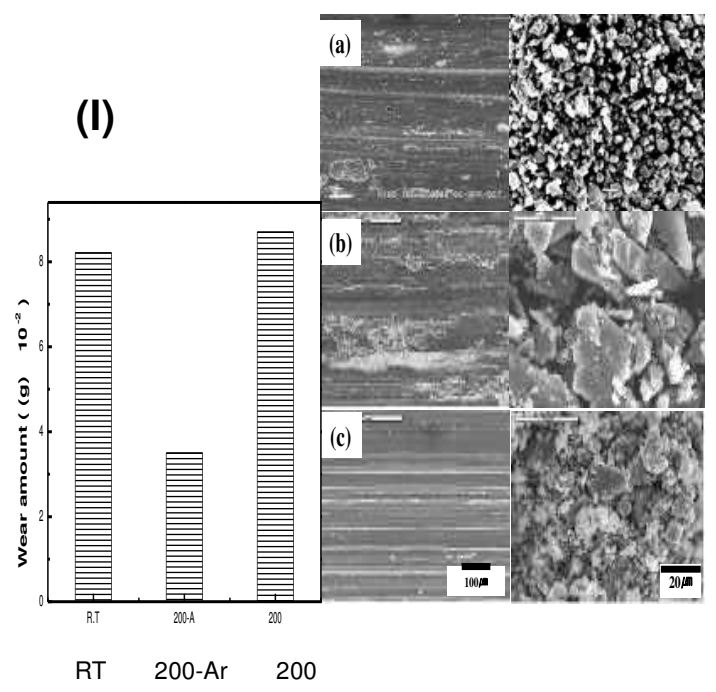

(II)

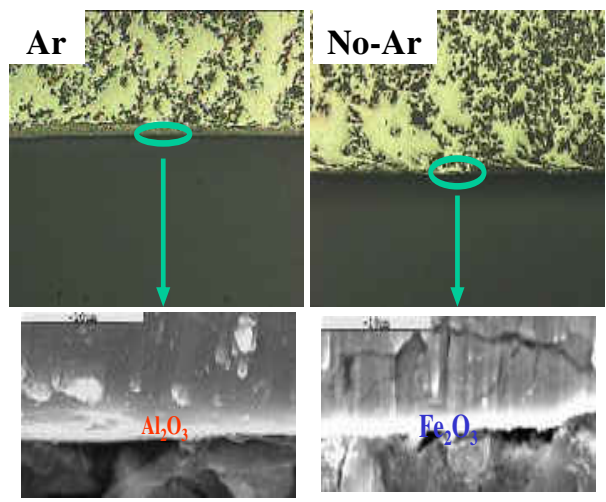

Figure 10. SEM of worn surface and debris according to the wear conditions in $3 \mu \mathrm{m}$ composite after exposure at $250{ }^{\circ} \mathrm{C}$ for $5 \mathrm{hr}$. (a) R.T (b) $200{ }^{\circ} \mathrm{C}$ (c) $200^{\circ} \mathrm{C}$-Ar.

\section{CONCLUSIONS}

The following conclusions can be derived from the results presented above:

1- The composite of $\mathrm{Al}$ as a matrix and $\mathrm{SiC}$ with size $(3,5$, and $10 \mu \mathrm{m})$ as reinforce with homogeneous distribution was fabricated by duplex process.

2- In the composites $(\mathrm{Al} / 10 \mathrm{wt} \% \mathrm{SiCp})$ manufactured by Duplex process, the sliding wear characteristics under conditions of ambient temperature, $200^{\circ} \mathrm{C}$ and $200^{\circ} \mathrm{C}$ Ar gas and microstructures were studied using OM, SEM.

3- The hardness of $\mathrm{Al} / \mathrm{SiC}$ composites increased with the decrease in $\mathrm{SiC}$ particle size and with $\mathrm{Ni}$ addition in both the as-cast and the as-heat exposed states.

4- In $\mathrm{Al}$ composite reinforced with $10 \mathrm{wt} . \% \mathrm{SiC}$, wear amount decreased with the decrease in particle size. The wearing amount of $200^{\circ} \mathrm{C}$ composite was greater than those of as-composites and $200^{\circ} \mathrm{C}$-Ar composite 


\section{REFERENCES}

[1] M. K. Surappa, "Aluminum matrix composites: challenges and opportunities," Sadhana, 2003; 28: 319-334.

[2] J. Goni, I. Mitexelena, and J. Coleto, "Development of low coat metal matrix composites for commercial applications," Mater Sci Technol, Vol. 16, 2000, pp 743-746.

[3] A. Pardo, M.C. Merino, S. Merino, F. Viejo, M. Carboneras and R. Arrabal, "Influence of reinforcement proportion and matrix composition on pitting corrosion behaviour of cast aluminium matrix composites (A3xx.x/SiCp)," Corrosion Science, Vol. 47, 2005, pp. 1750-1764.

[4] J.A. Garcia-Hinojosa, C. González R., J.A. Juárez I. and M.K. Surrapa, "Effect of grain refinement treatment on the microstructure of cast $\mathrm{Al}-7 \mathrm{Si}-\mathrm{SiCp}$ composites," Materials Science and Eng. A, Vol. 386, 2004, pp. 54-60.

[5] S. W. Kim, U. J. Lee, S. W. Han, D. K. Kim and K. Ogi, "Heat treatment and wear characteristics of $\mathrm{Al} / \mathrm{SiC}_{\mathrm{p}}$ composites fabricated by duplex process," Composites Part B: Engineering, Vol. 34, 2003, pp. 737-745

[6] E. P. Medécigo, M. I. Canul, M. R Reyes and A. Gorokhovsky, "Effect of processing parameters on the production of bilayer-graded $\mathrm{Al} / \mathrm{SiC}_{\mathrm{p}}$ composites by pressureless infiltration," Materials Letters, Vol. 56, 2002, pp. 460-464.

[7] S. S. Joshi, N. Ramakrishnan, H. E. Nagarwalla and P. Ramakrishnan, "Wear of rotary carbide tools in machining of $\mathrm{Al} / \mathrm{SiCp}$ composites," Wear, Vol. 230, 1999, pp. 124-132.

[8] R. Rodríguez-Castro, R. C. Wetherhold and M. H. Kelestemur, "Microstructure and mechanical behavior of functionally graded $\mathrm{Al} \mathrm{A} 359 / \mathrm{SiC}_{\mathrm{p}}$ composite," Materials Science and Engineering A, Vol. 323, 2002, pp. 445-456

[9] M. I. Pech-Canul, R. N. Katz and M. M. Makhlouf, "Optimum conditions for pressureless infiltration of $\mathrm{SiC}_{\mathrm{p}}$ preforms by aluminum alloys," Journal of Materials Processing Technology, Vol. 108, 2000, pp. 68-77.

[10] X. -P. Zhang, L. Ye, Y. -W. Mai, G. -F. Quan and W. Wei, "Investigation on diffusion bonding characteristics of $\mathrm{SiC}$ particulate reinforced aluminium metal matrix composites (Al/SiC $\left.\mathrm{S}_{\mathrm{p}} \mathrm{MMC}\right)$, " Composites Part A: Applied Science and Manufacturing, Vol. 30, 1999, pp. 1415-1421.

[11] M. Muratoğlu and M. Aksoy, "Abrasive wear of 2124Al-SiC composites in the temperature range $20-200{ }^{\circ} \mathrm{C}$," Journal of Materials Processing Technology, Vol. 174, 2006, pp. 272-276.

[12] I. Dutta, S. M. Allen, and J. L. Hafley, "Effect of reinforcement on the aging response of cast $6061 \mathrm{Al}-\mathrm{Al}_{2} \mathrm{O}_{3}$ particulate composite," Met Trans; $22 \mathrm{~A}, 1991$, pp 2553-2563.

[13] J. Y. Uan, L. H. Chen, and T. S. Lui, "On the extrusion microstructural evolution of Al-Al3Ni in situ composite," Acta Mater, 49, 2001, pp. 313-320. 


\section{خصائص البري ومقاومة الحرارة لمادة مركبة من الالومنيوم ومسحوق كربيد السليكون}

هذه المقالة تهدف إلي بحث خصائص البري لمادة مركبه من الالومنيوم ومسـحوق كربيد

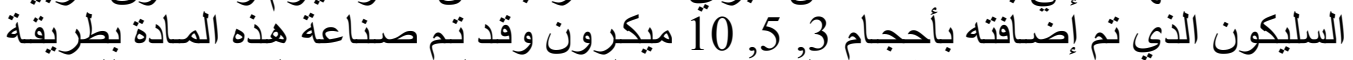

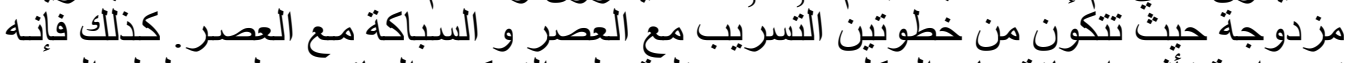

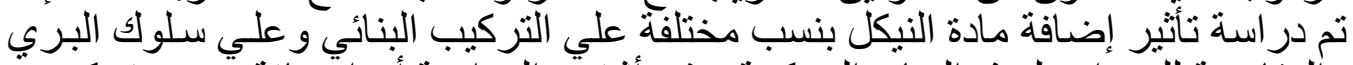

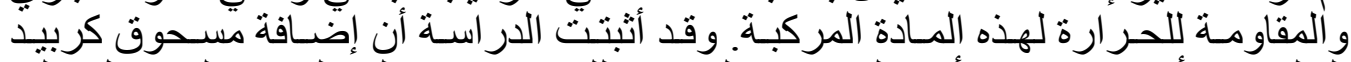

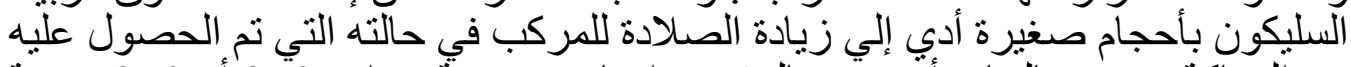

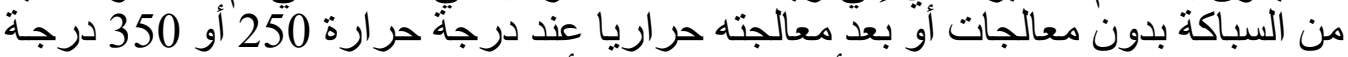

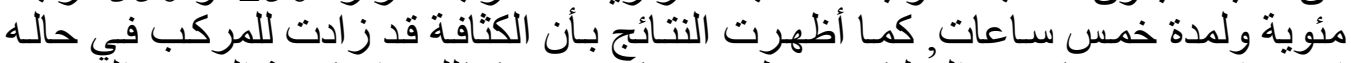

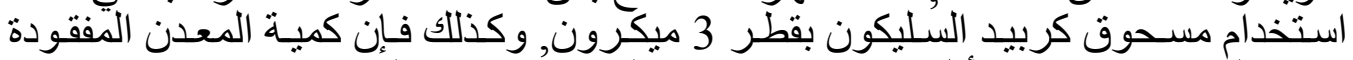

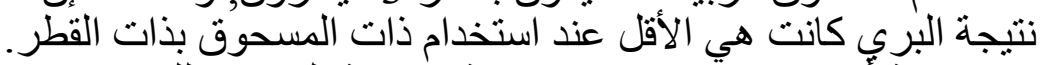

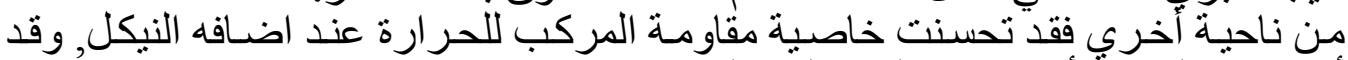

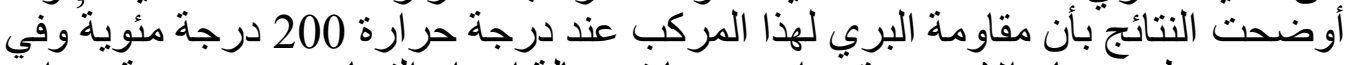

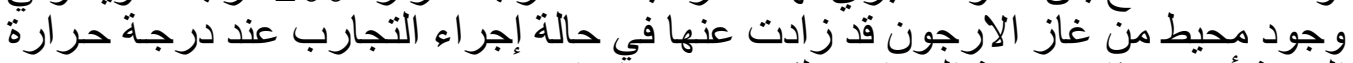

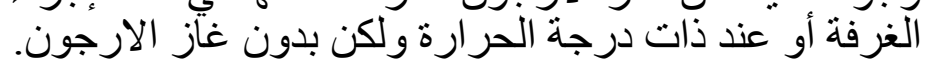

